\title{
Altyerre NOW: Arrernte dreams for national reconstruction in the 21st century
}

\begin{tabular}{c|c} 
Joel Liddle Perrurle & Barry Judd ${ }^{\mathbf{1}}$ \\
Northern Institute, Charles Darwin University & Northern Institute, Charles Darwin University \\
joel.liddle@cdu.edu.au & barry.judd@cdu.edu.au \\
\hline
\end{tabular}

Keywords: Indigenous nation building, Indigenous knowledge sovereignty, Arrernte people, central Australia, Indigenous research ethics

\section{Introduction}

In the period since the end of the white Australia policy in the early 1970s, Aboriginal peoples across Australia have worked tirelessly to revive and strengthen their identities through an active engagement with culture. ${ }^{2}$ In the context of systematic colonial-settler attempts to eliminate Aboriginal peoples and their cultural practices in the period 1788-1972, cultural revival has often required Aboriginal community leaders, activists and intellectuals to build relationships with non-Aboriginal institutions who hold knowledge about 'traditional' Aboriginal cultures and societies. While institutions such as museums, art galleries and universities were historically very prominent in the colonial dispossession of Aboriginal peoples - by confirming their status as 'primitives', 'savages' and a 'child-like' race unworthy of freedoms and rights associated with 'citizenship' (Haebich, 2008; Chesterman \& Galligan, 1997) - today these same institutions provide for the possibility that Aboriginal identity, culture and knowledge might be revived, regenerated and reconstituted in ways that sustain tradition and facilitate continuity into the future.

This paper provides a case study of research interactions between an Arrernte researcher and non-Aboriginal institutional repositories that hold significant collections of Arrernte material culture and cultural knowledge. This paper, although exploratory in nature, is designed to both document and give voice to Aboriginal people who are compelled to engage in research as a means to rediscovering their Aboriginal identities through private efforts to gain knowledge of their kin relationships, language, cultural practice and protocols, and rights to place. This paper does so by outlining how the research engagement with non-Aboriginal repositories is experienced by an Aboriginal researcher. In drawing attention to the experience of Aboriginal researchers, this paper is particularly concerned with questions of power and authority that implicitly raises larger questions about the moral and ethical legitimacy of competing claims to ownership. It is perhaps unsurprising that significant differentials exist between Aboriginal people seeking to conduct research that focuses on their family, people, country and the non-

1 This article is primarily authored by Joel Liddle Perrurle as an Arrernte man involved in personal and extended family and kin-based research activity. Significant editorial assistance has been provided by Barry Judd whose expertise in Australian Indigenous Studies is used to place the research experience described in relation to broader issues and theoretical frameworks that are useful to understand how power and authority operate in respect to Aboriginal-focused research activity that involves Aboriginal people and is impacted by the history of British colonialism and Australian race relations.

2 Readers should note that the White Australia Policy was not a single policy but a complex web of legislation, regulation and administrative practices. The period of the White Australia Policy commenced in 1901 with the passing of the Commonwealth Immigration Restriction Act (1901) and ended in 1973 with the Federal Labor government of Prime Minister Gough Whitlam removing racist clauses from the Immigration Act. The 1967 Referendum on Aborigines is considered an important moment in dismantling the White Australia Policy. 
Aboriginal institutional repositories whose power and authority determines who has the right to access 'their' collections. In central Australia, Arrernte researchers possess relatively little power to effectively negotiate access to non-Aboriginal institutional repositories of which they are effectively not custodians or managers, nor anthropologists or curators. Instead these researchers are forced to rely on the goodwill of individual administrators in order to gain access, but there are never any guarantees. In the apparent absence of guidelines and procedures that set out protocols of access for Arrernte research engagements, this situation often leaves Aboriginal researchers with feelings of frustration and anger as they perceive decisions regarding access to be governed by the administrative whim and caprice of individual 'gate keepers'. Feelings of deliberate exclusion also become manifest in respect to the history of Australian race relations. It is a widely held perception among many in central Australia that the politics of identity conspires in ways that make it far easier for non-Aboriginal researchers from faraway places to gain institutional access to institutional collections of Arrernte knowledge and cultural materials than it is for Arrernte people themselves. Indeed, the perception among Aboriginal peoples in central Australia is that non-Aboriginal institutional repositories direct much of their power and authority to block, stall and restrict the ability of researchers who claim an Aboriginal identity access to the cultural knowledge and materials generated by their own ancestors - be they kin or direct blood relatives.

The case study contained in this paper draws on the personal experience of an Arrernte man, Joel Liddle. It should therefore be noted that his experience makes no claim to be representative of all research interactions by researchers who claim an Aboriginal identity. The specificity of this case study recognises both the diversity of Aboriginal cultures that exist across the continent now known as Australia, and the differing degrees to which Australian repositories of Aboriginal cultural material are accessible to the Aboriginal peoples from whom their collections originate. This case study about Arrernte people in central Australia is written to act as a vehicle to chart and initiate what we, the authors, believe to be a very important, necessary and long-overdue conversation. Structures of power and authority continue to impede Aboriginal research efforts and the reconstruction of Aboriginal culture, and a significant outcome of this research activity is to highlight access by Aboriginal researchers to cultural materials as a necessary pathway to improved future health and well-being for Aboriginal peoples in central Australia and elsewhere.

\section{Theoretical Framing}

As a case study of power and authority the description and analysis of the relationship that operates between Aboriginal researcher and non-Aboriginal institutional frameworks might be understood in reference to the writings of several key authors whose conceptualisation of power relations in society provide useful frames for the case study contained in this paper. First, the concept of cultural hegemony developed by the Marxist thinker Antonio Gramsci is useful for understanding how elites manipulate national cultural beliefs, understandings, explanations, perceptions, values, and mores in ways that position their world view as the culturally dominant norm. According to Gramsci, the power relationships of society that are structured in ways that work to the benefit and financial and cultural enrichment of the elite are read as 'natural', 'normal', 'inevitable' and 'unchangeable' (McNally, Schwarzmantel, \& Ebooks Corporation, 2009; Adamson, 1980). Reading the relationship between Aboriginal researcher and non-Aboriginal institutional repository of Aboriginal culture and knowledge in reference to the concept of hegemonic power suggests that Aboriginal researchers present a threat to the elites who control the institutions in question. In this situation maintaining the status quo requires the perceived threat associated with Aboriginal researchers (i.e. cultural revival and, in central Australia for example, Arrernte national reconstruction) to be managed and mitigated 
via the imposition of access restrictions. Second, the concept of hegemony reminds us that the functionaries of institutional archives and museums have much to lose. The significant financial rewards associated with paid employment and long-term careers as anthropologists, curators and archivists and their claims to expertise, control and ownership over Aboriginal cultural materials and knowledge is at stake. Given this, resistance to Aboriginal access and suppression of community-driven research activity is unsurprising as this socially and economically entrenched 'class and race based' interest group seeks to protect its own power and authority against the threat of disempowerment and irrelevance posed by Aboriginal people committed to the principle of cultural autonomy. As contemporary Australia is governed by a settler-colonial state shaped by the historic processes of British imperialism and colonialism and, since 1901, by its own form of internal colonialism, the concept of cultural hegemony needs to be understood in respect to the particular power relations that exist between 'settler' and 'native' and that are rendered 'normal', 'natural' and 'inevitable' by the political, economic and social systems that have emerged in the colonial system.

While the ideological impact of the colonial system in social and psychological terms was detailed by Franz Fanon in the context of French North Africa (Fanon \& Philcox, 2004; Fanon \& Markmann, 2008), the work of the historian Patrick Wolfe is most relevant for gaining insight into how the cultural hegemony of Anglo-Australian colonialism operates in shaping power relations between Aboriginal and non-Aboriginal people. According to Wolfe, colonialism in Australia is characterised by the political and economic requirements of 19th century pastoralism that is structured as a zero-sum logic whereby the economic success of 'settlers' demands the elimination of the 'Aborigine' from the country which the settler also claimed and occupied (Wolfe, 1999). When the insights that Wolfe provides are considered in combination with Gramsci's concept of cultural hegemony, it might be said that the ideology of AngloAustralian society holds that Aboriginal peoples, issues, cultures and perspectives continue to be regarded as 'problems', a situation that directs the power and authority of elites to efforts, practices, actions, attitudes and responses that seek their elimination. In the 18th and 19th centuries efforts to eliminate the 'Aborigine' included shootings, poisoning, rape and murder. Later, legislative forms of elimination such as the infamous Aborigines Protection Acts were used. In the late 20th century the Land Rights Acts and Native Title has been applied as a way to legally eliminate Aboriginal peoples from claims to their Country. The history of Australia since 1788 suggests that the colonial imperative to eliminate the native has developed through ever more complex, subtle and invisible mechanisms from the blunt instrument of massacre, to legal elimination through the imposition of colonial definition of Aboriginality, to the institutional practices of the archive and museum to eliminate Aboriginal researchers by subtle and discreet denials of access.

In the case study outlined in this paper, we argue that non-Aboriginal institutional repositories of Arrernte and other Aboriginal knowledge and cultural materials seek to eliminate the Aborigine by stifling their research activities through a denial or delay in authorising access to their collections. Such elimination is a direct response to the assertions and motivations of Arrernte and other Aboriginal researchers who seek institutional access in order to engage in the revival and or strengthening of cultural knowledges, concepts, practices and outputs in ways that underpin the reconstruction of their Aboriginal nation. In our view such efforts that aim at a renaissance in Aboriginal thought, culture, identity and nation constitute a direct threat to the moral and ethical legitimacy of the settler-colonial state in Australia and the elites who benefit most from the status quo. The micro everyday impact for Aboriginal researchers is to experience relationships with non-Aboriginal institutional repositories as problematic, tense, frustrating and often shaped by an underlying degree of hostility. In central Australia, this situation of underlying hostility means that Arrernte researchers are made to feel that they have 'no business' accessing cultural materials and knowledge held by institutional repositories or indeed engaging in research activity at all. 


\section{The case study: Joel Liddle Perrurle and Arrernte research realities}

Ethnographic and anthropological research presents significant challenges to the Arrernte researcher, learner and broader community. Historically, research has been conducted by non-Indigenous academics and intellectuals employed during the frontier period to record ancient rituals of a race and culture expected to become extinct. The effects of displacement and loss of identity, language, political autonomy, agency and power presents very real issues for many Arrernte people today. Generally speaking, much of the research conducted today is designed to support either Land Rights or Native Title claims, determine the impact of developments on land like mining, or for sacred site protection, natural resource management and royalty distributions. Research conducted today is held within land councils, registered native title body corporations or museums and, once collected, is utilised by these institutions to inform their consultative work. This case study details the complexities Arrernte researchers face when trying to engage with representative bodies that hold extensive archives of the one of the most studied, well known, celebrated and reified Aboriginal tribes (now generally called language groups) in Australia. The processes of colonisation, assimilation, removal from traditional estates and on-going Government policy has bought enormous strains to bear upon Arrernte culture, which remained mostly unaffected during the first years of white arrival in central Australia (C. Strehlow, 1908; T. Strehlow, 1947). The loss of cultural knowledge through on-going targeted Government policies and practices that reward assimilation - including the NT Intervention and roll-back of bilingual education programs (Watson, 2009; Baehr \& Schmidt-Haberkamp, 2017; Judd, 2017) - has meant some people of Arrernte descent have had no access to traditional cultural processes of learning. This paper draws on my personal experience as a researcher and discusses the impacts a lack of access to archival records and potential cultural curriculum have on the broader Arrernte community and how this has a direct bearing on social, emotional and cultural health and wellbeing.

Traditionally, the methods of learning key elements of culture were engrained in Arrernte people from the earliest age, and the strict adherence to Altyerre (law) meant that each individual had key roles determined by complex and strictly adhered-to kinship arrangements that positioned them within our social, cultural and economic framework. For Arrernte children and youths, the relationship between absolute knowledge of country and landscape was not only key to their survival, but paramount to their understanding of Arrernte governance, religious practice, mythology and strictly defined areas of exclusion. From birth, every individual had a personal totem through their conception site, belonged to a totemic clan (through patrilocal marriage) and inherited their skin name within our kinship system Anpernirrentye through patrilineal descent. Conception and associated totemic relationship to that conception country fixed the future religious duties of each individual and the social relationships they maintained within their community.

The earliest European recording of this knowledge in central Australia in various Arrernte language-speaking areas was conducted by (but not limited to) Carl Strehlow (C. Strehlow, 1908), Baldwin Spencer and Frank Gillen (Spencer \& Gillen, 1904), TGH Strehlow (T. Strehlow, 1947) and later by historians, linguists, anthropologists and archaeologists who ultimately claimed that their knowledge and expertise encompassed Arrernte culture (Austin-Broos, 2009). Compared to pre-white incursions of the region, Arrernte today learn from surviving Elders and family structures, and by conducting further family research in an effort to relearn and rediscover our identities. Inevitably though, the ability to learn at the absolute level of our early generations has passed. We are influenced by the need to hold down full-time employment to support families (immediate, extended and kin), access to land is limited as many traditional estates are now occupied by pastoral stations, and the current-day Land Rights and Native Title systems often result in the sociocultural environment often times being contested and unfriendly and including unsupportive interactions. The effects of colonisation, social and 
political encapsulation within a settler-colonial state, and the impacts of assimilation policies enacted for more than 100 years have meant our culture (specifically Eastern/Central Arrernte, to which I belong) has been deeply and sometimes irreversibly supressed. Sadly, some traditions and practices, ancient songs and dances, are now irretrievably lost. Relearning culture is paramount to Arrernte people who, like me, may not have had the privilege of learning within the family home or in the context of living in a remote community 'on Country'. Many Arrernte are descendants of Stolen Generations, were schooled in convents and religious institutions, or have mixed lineage that saw many in our parents' and grandparents' generations harshly disciplined for speaking our language and strongly discouraged from partaking in cultural practices that reaffirmed our Altyerre (Green, 2012).

My interest in research stems from a need to understand the Arrernte worldview to the best of my ability. The understanding of complex land, social and spiritual governance systems that exist and define our identity is integral to being Arrernte. It is only with knowledge of these highly intricate systems that you can really understand the Arrernte worldview and gain relevance from terms like 'connection to country'. Prior to moving to Alice Springs, I had spent yearly trips through my childhood, teens and early twenties travelling to central Australia with my family, which exposed me to language and the significantly more visible presence of Aboriginal people in Alice Springs compared to where we lived in Canberra and Melbourne. Inevitably I had many questions of who I was, what my Aperle (Nanna) was saying when she spoke language and why (in Canberra and Melbourne) I was targeted in school or weekend sport for my racial difference. The questions about identity nagged me, but during these formative years I had no agency to find answers to those questions with any insight or coherence. Unfortunately for many Aboriginal people, these are the same questions that they live with and - while they go unanswered - the health of individuals and communities is seriously and adversely impacted. Unequivocally, if, through cultural reengagement and learning, we are able to instil pride into many of our people who have experienced loss of culture, language and identity, we would address issues that see Aboriginal people suffer with all manner of socioeconomic disadvantage. This disengagement, particularly among Aboriginal men, leads to incarceration at rates higher than ever, ill health, and lack of engagement in meaningful employment or education, and results in our children experiencing one of the highest rates of suicide anywhere in the world.

In 2007 I became aware of a series of ethnographic works completed in the late nineteenth and early twentieth centuries in and around Alice Springs by Baldwin Spencer and Frank Gillen called The native tribes of Central Australia (Spencer \& Gillen, 1899). This book revealed cultural practices, kinship and family terms, language, and ceremonial performances and spoke of sites of significance. This particular focus of the book was the extravagant traditional Angwerre festival, held at the Alice Springs Telegraph Station in 1896-1897 that spanned several months through that summer. When I first scanned the book I saw phonetic Arrernte terms that I couldn't understand and places I had never heard of. I was in awe of the absolute devotion to performance of elaborate ceremonies Arrernte people had. These people were distinguished, healthy and of great stature. Most impressive were the photos of the ceremonial leaders that immediately identified them as men of high degree. As I read It quickly became apparent that learning about my heritage would help deal with struggles I had with identity, racism and questions of belonging, as well as allowing me to reconnect with my Arrernte heritage, language, Country and traditions that I have, since youth, desperately yearned to know and understand.

Often, I would write to various institutions about accessing public materials like genealogies, photographs, diaries and letters. Sometimes l'd encounter suspicion regarding my unofficial status as a hobby researcher undertaking the activity to relearn my cultural identity in my unpaid private time. My lack of an official affiliation with a research institute or university certainly did not help. Frustratingly, l'd see non-Arrernte researchers affiliated with universities 
in Melbourne, Sydney and Canberra attending these same institutions with seemingly free access to the same records and materials I wanted to learn from but was denied access to. Obvious cultural assumptions were made to what exactly my intentions were, and it's always challenged me to communicate my actual intentions while being met with suspicion. I have a sense of responsibility to the materials that I research, and this is the responsibility to my immediate community and Aboriginal Australia more broadly, and the role I hope to play into the future. Without doubt, the strictest of processes need to be in place to protect restricted secret and sacred materials; however, many other archives exist like oral history interviews, photographs, diary entries, publications, genealogies, day-to-day artefacts or placenames that could be extracted and made accessible and which would re-enrich Arrernte people today. Often problematic is the stalemate that develops between collections and the cultural interests of Aboriginal people who possess familial relationships to the ancestors whose cultural knowledge and artefacts are documented in the archive. Many Aboriginal people are desperate to reconnect with their more ancient heritage. Without the ability to learn traditional rules and processes as children, teens, or even adults, some unwittingly have a careless approach to these very important collections. While we know that archives of information exist 'about land' there is currently no collated, formulated, research based, culturally appropriate curriculum developed by Arrernte researchers in collaboration with these materials that could be utilised to re-engage frustrated members of our community, reteach those disengaged through systematic assimilation, and heal those currently living socially dysfunctional lives. The production of such courses and the materials to support them would, of course, require the guidance of those with cultural authority. We should not underestimate the positive outcomes in terms of strengthening identity, improving health and well-being, and a general re-skilling and re-intellectualising of the Arrernte nation as the basis of future economic self-sufficiency through interactive crash courses with culture and a relearning of 'proper way'.

In the current era, how Arrernte and other Aboriginal culture and knowledge is represented in academia and the way Aboriginal people are moulded to suit western political systems and legislation continues to raise important issues about their representation in mainstream Australian media and the role repositories of cultural materials and knowledges play in replication of colonial stereotypes of Aboriginal people as deficient, inferior or 'other' (Said, 1978; Attwood \& Arnold, 1992). We must ask who it is who really benefits from the research archives and vast Aboriginal collections of material culture or from the numerous and varied restrictions placed on community access of the materials. Is it the institution? Is it the professionals who use the materials to claim intellectual ownership and expertise based on Arrernte culture, history, language, and people? Is it the traditional owners in the model of 'ownership' that has become corporatised and monetarised in the period since the 1975 NT Land Rights Act became law? Is it a malignant alliance of all these things that works to stifle independent and grass-roots based Arrernte efforts to re-assert sovereignty over their cultural materials and therefore their Country and identity?

The appropriateness of accessing research collections means inevitably there must be an understanding of what is accessible and what is not. Museums, universities and institutions all have ethical processes in place to regulate access to the materials they hold. Rightfully so, access to these collections today is strictly available only to those who have the cultural credentials, totemic relationship, experience and knowledge, or have gained permission from those who do. Much of what was recorded by Spencer and Gillen, and later TGH Strehlow, includes the sacred performance of rituals and ceremonies, sacred men's objects (Tywerrenge) and the vast numbers of video and audio reels that captured ceremonies in real time images and sound. This is particularly the case with the TGH Strehlow collection as he was requested by his informants to record their rituals for 'safe keeping', as the changing world of the Arrernte in central Australia in the period between the 1930s and 1960s meant those who would normally receive these through the usual traditional inheritance were often 
not yet in a position to inherit. For example, many were unable to do so because they had been forced onto mission stations, to The Bungalow in Alice Springs, or removed interstate, making cultural transmission between older and younger generations difficult if not impossible. Others had little interest in receiving the Arrernte cultural learning, which they too had increasingly come to consider irrelevant to the 'modern' world.

However, there are considerable materials that exist in many institutions that are not of a secret or sacred nature. Since colonial incursions in central Australia commenced in the latter part of the 19th century, Arrernte people have been one of the most researched of all Australian Aboriginal groups. In many ways, Arrernte have become the emblematic foundation of all colonial representations of Aboriginal peoples throughout the continent. The term 'Dreamtime' for example, popularised and exported through the writings of Spencer and Gillen, is illustrative of such (mis)representations and (mis)appropriations of Arrernte culture and identity. Today, how knowledge is used is different to how it was used in what is considered the 'traditional' Aboriginal society of the past. Much study of the archives has been undertaken to support land claims or for consultation processes over land development but they are rarely used for the growth, identity strengthening, re-engagement, collective knowledge, health or wellbeing of Arrernte people; in other words for continuing and contemporary Arrernte tradition. Institutional priorities sometimes diverge with cultural practice and on-going obligation to maintaining the health of country. Meanwhile, paintings and rock engravings fade out, water holes and soakages silt up, sites are destroyed by exotic weeds and wildfire, and important totemic species become extinct as a result of unchecked feral animals - cats, rabbits, camels and horses. It is often essential, and an unfulfilled passion, for Arrernte people to relearn and re-engage in their culture; however, many are frustrated with and confused by the positions taken by western academic and political institutions towards contemporary tradition, and the systems of power that are so hard for an Arrernte person to navigate. This is particularly the case for those in our community who have limited English literacy, numeracy, educational background, or understanding of modern-day western governance systems that exist within representative bodies.

Cultural knowledge encompasses social wellbeing, health, personal growth and spiritual wellbeing; however, in the current climate we are seldom producing materials that will enrich the lives of our community. With the explosion of new technologies like phones, tablets and $\mathrm{Wi}-\mathrm{Fi}$, can these mediums be utilised to provide education platforms? Instead of having clear pathways and directives to develop the curriculums and cutting-edge communications technology platforms that might carry them as effective means to re-engage our youth, we encourage sport or music as the only viable avenues to achieve a meaningful and productive life. Additionally, with remote engagement in education at critically low levels, having locally based culturally appropriate curriculums to re-engage our youth is imperative for building selfesteem and self-awareness.

The most notable absence in historical ethnographic and anthropological research is the contribution of Arrernte women. Through the early contact years and at least until TGH Strehlow was completing his life-long research in the early 1970s, cultural research was undertaken by non-Aboriginal male researchers, exclusively focussed on Arrernte men's culture. This isn't by default; however, it is a reflection of the strict gender and cultural differences that meant Arrernte men only spoke of men's cultural business to researchers who were also male. Arrernte women and the cultural practices and knowledge of women were not made available for documentation through ethnographic research. Because there were no female researchers present during this time Arrernte women's culture was not recorded or documented and is not well represented in contemporary museums or collections. This presents difficulties for the Arrernte female learner looking for archival materials to enrich her identity, and more femalespecific Arrernte research needs to be undertaken to better encapsulate female cultural perspectives, practices and knowledges. 
When I was a teenager, my Nanna Emily Liddle (née Perkins) mentioned to me the mythical Uremerne Rockhole, place of the Untyeye Altyerre (Corkwood Honey Dreaming) and her relationship to that land and women's Altyerre through her maternal grandmother, Untyeyampe Perrurle (also known as Maggie Kana). From the time I returned to central Australia, it became a personal mission to rediscover it and survey the landscape to see what the health of the Country was. In one of my Nan's oral histories she mentioned being at the Rockhole as a young girl for a women's ceremonial gathering, so it was important for me to retrace her steps in an attempt to reconnect with her memories of that time and the events of the past. It was also through the research that I became aware of my Aunty, Kathleen Kemarre Wallace, because of our shared ancestry. Aunty Kathy has since become one of my most important cultural teachers and mentors as she shares the same interests in land, visiting sites and country, hunting and the on-going health and maintenance of our culture. Today in central Australia, someone like me has the privilege to be able to engage in language and cultural learning through the tireless, lifetime works of senior women like Kathleen Kemarre Wallace, Veronica Perrurle Dobson (Hayes), Margaret Kemarre Turner, to name only but a few. These relationships reflect the continued importance that women play and will continue to play in the renaissance of Arrernte culture. It is imperative that Arrernte women also have access to repositories of cultural material and knowledge, particularly in respect to genealogical information, as knowledge of family and kin is central to women's business.

Access to archival materials creates opportunities for the replenishment of country and revival of culture. Throughout my research, I have become aware of place names and stories for country that indicate sites, events and ancestors from the Altyerre. Senior Arrernte man Kwementyaye Stuart once said, "Every hill got a story". In no place is that sentiment truer than in Alice Springs and central Australia. Though access to collections has at times proven difficult it has allowed me to learn about country, place names and areas of great religious practice while also providing me with a culturally enriched appreciation of land management and conservation. I have travelled to sites to assess the impacts of noxious weeds like buffel grass and seen ancient paintings and engravings destroyed by hot buffel grass fires. I have seen soakages and waterholes silted up, full of algae and dead animals where once they were pristine sources of life for our ancestors. I have researched important totemic mammals like the Antenhe (possum), Aherte (bilby) and Akwerre (bandicoot) all but extinct now in this region because of unchecked feral animals. Relearning creates a new conversation: what do we need to do for country now? What is the role of individuals - is it only to be concerned with country for the monetary rewards from royalty distributions or to be invited to a land council meeting to discuss outside economic interests? Or is it to visit, look after and maintain so that our history and knowledge for country extends to future generations? How can these repositories, archives and representative bodies assist us in re-enriching our community? Where learning can sustain and enrich country, cultures and languages and has proven health, holistic and socioeconomic benefits to community, support for research-based cultural curriculums within our education systems, Arrernte researchers are critical to the on-going support and maintenance of culture. Replenishment of culture through learning and current-day contributions to the archives will serve to enhance our community, and provide employment and economic pathways, and we will start to make marked change in the health and wellbeing of Arrernte people.

\section{Concluding Remarks}

The case study of an Arrernte researcher outlined above documents the experience of Joel Liddle Perrurle in attempting to harness research as a tool for cultural revival, the rediscovery of identity, the reconnection to Country and ultimately the reconstruction of the Arrernte people into a viable, healthy social and political nation that meets the needs of a people who live in the context of on-going contemporary settler-colonialism. The problems and complexities that he identifies suggests Aboriginal researchers need to remain focussed, determined and highly 
resilient in their support of what might be broadly called Aboriginal national reconstruction. The power and authority that institutional repositories of Aboriginal knowledge and cultural materials hold over Aboriginal researchers' ability to access 'their' collections can be read as a structural problem when referenced against the concepts of cultural hegemony and the colonial impulse to eliminate the 'Aborigine'. In the colonial context of Australia, Gramsci's idea that intellectuals and scholars might play a key disruptive role in undermining the ideological power of elites must be jettisoned as those elites who control museums, galleries and universities are found to regularly uphold the logic of Anglo-Australian colonialism in their attempts to eliminate the Aboriginal researcher by means of barring and restricting their ability to access institutional collections.

The solution to the problems that Aboriginal researchers may encounter as they attempt to access the cultural material and knowledge of their ancestors in order to relearn culture in order to re-active their personal identities as Aboriginal people and that of their immediate family and extended kin as a self-determining community or nation may be varied and complex. We believe that solutions might start with an act of recognition that accepts that Aboriginal people in the 21st century are no longer merely the objects of museum and archival collections but seek to actively engage with institutional repositories as independent and communitybased researchers in their own right. Their right to research and their right to access is one that is ultimately based in the immediate relationship they have with the cultural materials and knowledge held by the archive, museum or university. Denying the right of the living to communicate with, and learn from, their own ancestors seems a denial of human rights as well as a denial of the rights attributable to Indigenous peoples under various United National charters and declarations. Change, however, will require more than acts of recognition, and we believe that solutions to the issues in respect to central Australia will require Arrernte people to take more control in how questions of Aboriginal researcher access to institutional repositories are handled, addressed and determined. We look forward to the day when Arrernte people are the anthropologists, the archivists, the libraries and the mangers of the institutional repositories that hold and keep a cultural inheritance that rightfully belongs to them.

\section{Translations}

Altyerre: The creation of the world and all things in it. Altyerre includes moral codes of conduct, land and totemic inheritance, epic accounts of ancestral characters and their journeys across country, sacred sites, a system of social behaviour, and a life force. Altyerre refers to the world as both continuous and permanent, for all time since its creation.

Also, laws, strictly defined rules for living, social and cultural governance structures.

Known in English as 'The Dreamtime'.

Perrurle: One of the Eight Arrernte skin names. Known in English as 'skin name'. From the Kemarre/Perrurle patriomoietie. Others include Ampetyane/Ngale, Pengarte/Penangke, Kngwarraye/Peltharre.

Anpernirrentye: Kinship system. Includes the eight Arrernte skin names. Dictates how Arrernte inherit land, roles and responsibilities, marriage, rules for living, family, creation and identity.

Kwementyaye: Name used out of respect for someone who has passed away.

Aperle: Fathers, mother. Paternal grandmother. 


\section{References}

Adamson, W. (1980). Hegemony and revolution: A study of Antonio Gramsci's political and cultural theory. Berkeley: University of California Press.

Attwood, B., \& Arnold, J. (1992). Power, knowledge and Aborigines. Bundoora, Vic.: La Trobe University Press in association with the National Centre for Australian Studies, Monash University.

Austin-Broos, D. (2009). Arrernte present, Arrernte past: Invasion, violence, and imagination in indigenous central Australia. Chicago: University of Chicago Press.

Austin-Broos, D., \& Myers, F. (2011). A different inequality: The politics of debate about remote Aboriginal Australia. Crows Nest, NSW: Allen \& Unwin.

Baehr, E., \& Schmidt-Haberkamp, B. (2017). 'And there'll be NO dancing': Perspectives on policies impacting Indigenous Australia since 2007. Newcastle Upon Tyne: Cambridge Scholars.

Chesterman, J., \& Galligan, B. (1997). Citizens without rights: Aborigines and Australian citizenship. Cambridge: Cambridge University Press.

Fanon, F., \& Markmann, C. L. (2008). Black skin, white masks (new ed.). London: Pluto Press.

Fanon, F., \& Philcox, R. (2004). The wretched of the earth / Frantz Fanon, translated from the French by Richard Philcox with commentary by Jean-Paul Sartre and Homi K. Bhabha. New York: Grove Press.

Green, J. (2012). The Altyerre story - 'Suffering badly by translation'. The Australian Journal of Anthropology, 23, 158-178. doi:10.1111/j.1757-6547.2012.00179.x

Haebich, A. (2008). Spinning the dream: Assimilation in Australia 1950-1970. North Fremantle: Fremantle Press.

Judd, B. (2017). Sporting intervention: The Northern Territory National Emergency Response and Papunya Football. In Baehr, E. \& Schmidt-Haberkamp, B. (Eds.), 'And there'll be NO dancing': Perspectives on policies impacting Indigenous Australia since 2007. Newcastle Upon Tyne: Cambridge Scholars.

McNally, M., Schwarzmantel, J., \& Ebooks Corporation. (2009). Gramsci and global politics: Hegemony and resistance. Hoboken, NJ: Taylor \& Francis.

Said, E. W. (1978). Orientalism. New York: Pantheon Books.

Spencer, B., \& Gillen, F. J. (1899). The native tribes of Central Australia. London: Macmillan.

Spencer, B., \& Gillen, F. J. (1904). The northern tribes of Central Australia. Melbourne: Macmillan and Co.

Strehlow, C. (1908). Die Aranda Und Loritja-Stamme in Zentral-Australien. Hamburg: Joseph Baer and Co.

Strehlow, T. (1947). Aranda traditions. Carlton, Vic: Melbourne University Press.

Watson, I. (2009). In the Northern Territory intervention: What is saved or rescued and at what cost? Cultural Studies Review, 15(2), 45-60, available at SSRN: https://ssrn.com/abstract=2476811

Wolfe, P. (1999). Settler colonialism and the transformation of anthropology: The politics and poetics of an ethnographic event (Writing Past Colonialism series). London: Cassell. 